\title{
Institucinės ekonomikos teorijų raiška viešųjų pirkimų procese
}

\author{
Simona Ereminaitė \\ Mykolo Romerio universitetas \\ Valakupiu g. 5, LT-10101 Vilnius, Lietuva \\ doi:10.13165/VPA-14-13-2-07
}

\begin{abstract}
Anotacija. Straipsnyje analizuojamos institucinés ekonomikos teorijos ir ju dedamosios viešuju pirkimu procese. Ypatingas demesys skiriamas instituciju ir ju veiklos efektyvumo viešuju pirkimu procese išgryninimui. Mokslinès literatūros lyginamoji analize leidžia daryti prielaida, kad instituciné aplinka yra ekonomikos viešuju pirkimu proceso organizavimo ir igyvendinimo augimo pasekme ar priežastis. Tinkamos institucijos užtikrina nuosavybès teisiu apsauga, žema korupcijos ir biurokratijos lygi, teisès viršenybès principo igyvendinima, formuoja palankia institucinę aplinka ekonomikos augimui ir plètrai. Efektyvi institucinè struktūra valstybèje sukuria paskatas rinkos dalyviams investuoti i fizini ir žmogiškaji kapitala bei kurti novatoriškus produktus, kurie ilgalaikeje perspektyvoje turi tiesiogini bei teigiama poveikị šalies ekonomikai.
\end{abstract}

Raktažodžiai: institutas, institucija, institucionalizmas, neoinstitucionalizmas, ekonomikos teorija, viešieji pirkimai.

Keywords: institute, institution, institutionalism, new institutionalism, economic theory, public procurement.

\section{İvadas}

Viešųjų pirkimų organizavimo ir ịgyvendinimo mechanizmas suprantamas kaip viena iš aktualiausių ekonomikos problemų, taip pat viena iš potencialiausiu sékmingos viešosios politikos igyvendinimo priemonių, kuria galima ne tik sukontroliuoti pinigų srautus valstybejje, bet ir manipuliuoti korupcijos atsiradimo galimybèmis [23, p. 67]. 
Remiantis institucionalizmo kaip savarankiškos ekonomikos teorijos kryptimi, viešųjų pirkimų procesas gali būti suprantamas kaip institutų visuma, pasižyminti ypatingais tarpusavio ryšiais tarp perkančiųjų organizacijų ir tiekejjų bei daranti ịtaką ekonominei raidai valstybėje. Institutas viešųjų pirkimų procese susideda iš: 1) formalių taisyklių, reglamentuojančių viešųjų pirkimų tvarką, bei neformalių santykių tarp perkančiųjų organizacijų ir tiekejjų, turinčių poveikị tiek jų tarpusavio ryšiams, tiek jų bendriems susitarimams bei ūkinès veiklos vystymui; 2) prievartos priemonių, užtikrinančių nustatytų viešųjų pirkimų tvarkos normų laikymąsi, sankcijų bei valstybinès prievartos ignoruojant Lietuvos Respublikos viešųjų pirkimų teisinę bazę. Viešajame sektoriuje viešieji pirkimai apima dominuojantị viešųų pirkimų tarnybų vaidmenį, teisètvarkos procesus, sveikatos, socialinès tarnybos, išsimokslinimo, gynybos, transporto ir aplinkos apsaugos klausimus, todèl siekiant ịgyvendinti viešosios politikos tikslus bei patenkinti pilietinę visuomenę, viešojo sektoriaus organizacijų pirkimų apimtis yra daug platesnè negu privačiame sektoriuje [17].

Viešieji pirkimai yra palyginti nauja viešojo sektoriaus institucijų praktika, siejama su Naujosios viešosios vadybos idejomis perimti verslo valdymo principus ir juos pritaikyti viešųjų institucijų veikloje, tokiu būdu taupyti valstybès lěšas, jas efektyviau paskirstyti, skatinti viešojo ir privataus sektorių bendradarbiavimą. Institucionalizmo ištakos siekia XIX-XX amžių sandūrą, kai ypatingai buvo koncentruojamasi ị socialinị ir ekonominị vystymąsi valstybejje, ekonominių problemų sprendimą, tinkamų sprendimų viešajam ir privačiam sektoriui paiešką, neskirstant pirminių ir antrinių institutų, o juos analizuojant kaip visumą viešųjų pirkimų procese.

Tikslas - išanalizuoti institucinès ekonomikos teorijų raišką viešųjų pirkimų procese, numatant viešujų pirkimų tvarkos tobulinimo galimybes ekonominiu požiūriu.

\section{Uždaviniai:}

1. Apibrèžti viešųjų pirkimų sampratą klasikinio institucionalizmo teorijoje.

2. Išanalizuoti neoinstitucionalizmo ekonomikos teorijas viešųjų pirkimų procese: nuosavybės teisių, transakcijų (sandorių), sutarčių, visuomeninio pasirinkimo ir agentų.

3. Išnagrinèti ir įvertinti institucionalizmo raišką viešųjų pirkimų proceso etapuose ir numatyti viešųjų pirkimų tvarkos tobulinimo galimybes.

Metodai: loginè analizè ir sintezè, lyginamoji analizè, mokslinès literatūros, teisinès bazès, internetinių šaltinių analizè.

\section{Viešųjų pirkimų samprata klasikinio institucionalizmo teorijoje}

Pirkimų sampratos identifikavimas yra svarbus analizuojant institucines ekonomikos teorijas ir jas vertinant ekonominiu požiūriu. Mokslinèje literatūroje pateikiama skirtinga pirkimų samprata. Visų pirma, pirkimas yra sutartis, pažyminti 
prekès įsigijimą, bendradarbiaujant viešojo ir privataus sektoriaus organizacijoms, kartu tai abipusis susitarimas tarp pardavejo ir pirkejo, teisiškai patenkinantis kiekvieno dalyvio poreikius arba sutartis tarp tiekejjo, turinčio teisę parduoti prekę, ir pirkejjo, galinčio ją pirkti už nustatytą kainą, kurios dydị lemia tiekèjo ir pirkèjo susitarimas $[9 ; 14 ; 15 ; 38]$.

Remiantis Lietuvos Respublikos viešųjų pirkimų ịstatymu, viešasis pirkimas suprantamas kaip perkančiosios organizacijos atliekamas prekių, paslaugų ar darbų pirkimas, kurio tikslas - sudaryti viešojo pirkimo-pardavimo sutartị. Viešieji pirkimai yra susiję su prekių ir paslaugų pirkimu bei darbų užsakymu, kuriuos perka arba užsako paprastai viešieji subjektai (pvz., valstybinès arba vietinès valdžios įstaigos ir joms pavaldžios organizacijos) [25]. Analizuojant klasikinę (amerikietiška) institucionalizmo teorija viešuosiuose pirkimuose, galima pastebèti laipsnišką šios teorijos augimą bei visuomenei priimtinų institutų formavimosi procesą ekonominiu, politiniu, vadybiniu bei teisiniu požiūriais (žr. 1 pav.).

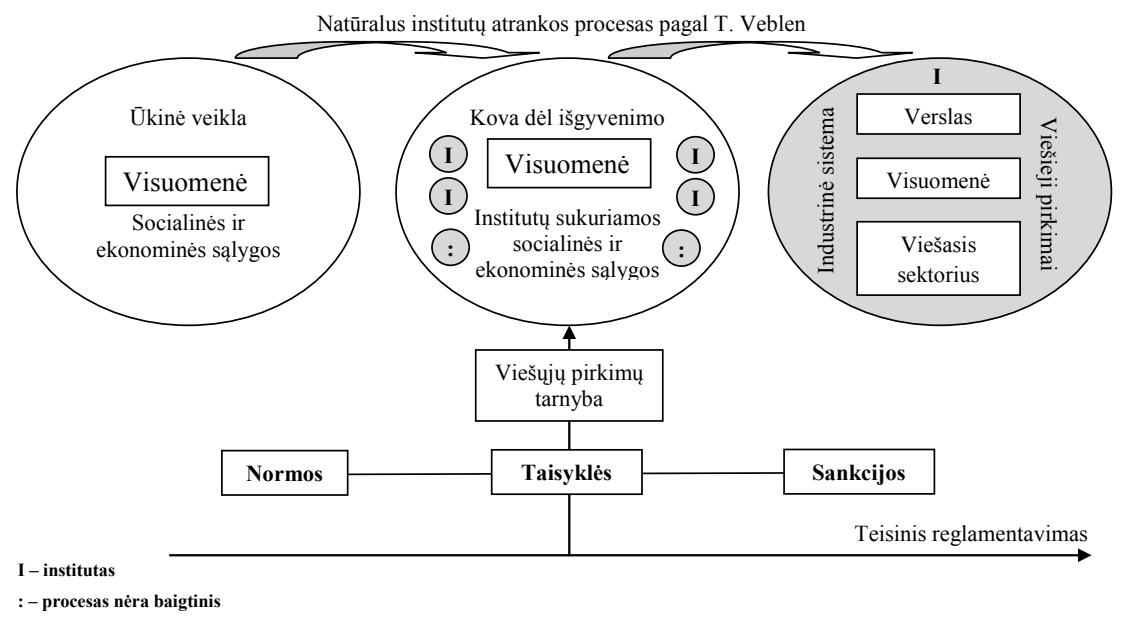

1 pav. Klasikinės institucionalizmo teorijos identifikavimas viešuosiuose pirkimuose [sudaryta remiantis $20 ; 33 ; 40$ ]

Istoriškai klasikinè institucionalizmo teorija leido suskirstyti visuomenę pagal konkrečią ūkinę veiklą ir santykius, kuriuos tiesiogiai veikia socialinės ir ekonominès sąlygos. Pasakytina, kad pirkimo procesai buvo galimi jau priešistoriniu laikotarpiu, kai, be ūkinès veiklos ir keitimosi prekèmis, paslaugomis ir darbais, valstybės nebūtų galëjusios egzistuoti. Kitas etapas natūraliai leido susiformuoti institucinei sistemai, identifikuoti institucijas bei klasifikuoti jas pagal atliekamas funkcijas. Vertinant institucijų būtinumą viešųjų pirkimų procese, galima teigti, kad be teisinio reguliavimo, institucijų įsikišimo ir kontrolès užtikrinti ūkinės veiklos skaidrumą būtų neįmanoma. Galiausiai, formuojantis industrinei sistemai 
santykiai visuomenèje, viešojo ir privataus sektorių bendradarbiavimas tampa vieni iš svarbiausių viešosios politikos svertų orientuojantis ị ekonominị naudingumą viešajam interesui. Mokslinès literatūros analizè leidžia teigti, kad viešieji pirkimai priskiriami antrajam institucionalizmo etapui XX amžiaus devintajam dešimtmečiui, t. y. 40-50 metu po Antrojo pasaulinio karo, kai labiausiai įsitvirtino Naujosios viešosios vadybos idèjos viešuosiuose pirkimuose [40, p. 373]. Vèliau padèti viešųjų pirkimų teoriniai pagrindai, apibrěžta viešojo pirkimo sąvoka.

Pagal J. Commons, analizuojant viešuosius pirkimus negalima ignoruoti teisės principų, psichologinių aspektų, etikos ir politikos nuostatų integravimo, kas turi tiesioginę ịtaką verslo ciklų formavimuisi ekonomikoje [33, p. 1]. Normos ir taisyklès yra pagrindiniai institucinės aplinkos elementai viešųų pirkimų procese, kadangi čia ekonomikos subjektai vykdo savo pasirinkimus. Norma gali būti apibrèžiama kaip žmonių elgesys, siejantis individo vertybes ir jo kasdieninį elgesį. Norma apibrèžia žmogaus elgesį skirtingose situacijose ir jos vykdymas gali būti savanoriškas ar sankcionuotas (paremtas socialinėmis, ekonominėmis ir teisinėmis procedūromis). Galima teigti, kad viešųjų pirkimų procese norma gali būti suprantama kaip svarbiausias ekonomikos subjektų elgesi koordinuojantis reguliatorius, turintis tiesioginę įtaką ekonomikos vystymui, pasitikejimui valstybinėmis institucijomis ir verslo atstovais, visuomenès pasitikejjimo lygio užtikrinimui, korupcijos masto šalyje kontroliavimui. Tokiu būdu sukuriama efektyvi sankcijų taikymo sistema, nesilaikant viešųjų pirkimų procesą reglamentuojančių normų.

Švedu sociologinio institucionalizmo atstovas Karl Gunnar Myrdal (1898-1987) orientavosi ne tik ị ekonominius procesus valstybeje, tačiau kartu akcentavo politinių tikslų svarbą. Vadinamoji Stokholmo mokykla paskatino ūkio planavimo, tarptautinių ekonominių ir politinių institucijų atsiradimą šiuolaikinių valstybių valdymo sistemose [8]. Lietuvos Respublikos narystė Europos Sąjungoje suteikia plačias galimybes šalies verslininkams konkuruoti bei igyti pranašumą kitų tiekẻjų atžvilgiu. Analizuojant viešųjų pirkimų teisinę bazę, galima pasiremti Stokholmo mokyklos atstovo Karl Gunnar Myrdal išplètotu kumuliatyviniu principu, pagal kuri keičiantis vieno veiksnio poveikiui, kinta kitų veiksnių poveikis. Atkūrus Lietuvos Respublikos nepriklausomybę ir pradejjus šalyje formuotis laisvajai rinkai, kilo būtinybė reglamentuoti už visuomenès lěšas vykdomus pirkimus. Tam buvo priimta daugybè teisès aktų, reguliuojančių viešųjų pirkimų sritị. Pastebėtinas Lietuvos Respublikos kaip teisinès valstybès atsilikimas, daugiausia susijęs su neatitinkančiais tuometinio laikotarpio institutais ir institucijomis, kas formavo ekonominį, socialinị ir dvasinį gyvenimą. Tik $1995 \mathrm{~m}$. balandžio $12 \mathrm{~d}$. Lietuvos Respublikos Vyriausybe patvirtino konkretesnes ir aiškesnes Valstybinio pirkimo laikinasias taisykles, reglamentuojančias pirkimų tvarką bei procedūras. Šis teisės aktas buvo pirmas šiuolaikinis viešuosius pirkimus reglamentuojantis ịstatymas Lietuvoje, kuris užtikrino konkurenciją, procedūrų skaidrumą ir atvirumą, tiekejjų lygiateisiškumą. Valstybinio pirkimo laikinosios taisykles Lietuvos Respublikos Seime priimtos 1996 m. rugpjūčio 13 d., ìsigaliojo - nuo 1997 m. sausio 1 d. [23, p. 67; 37]. 
Aktuali problema, siejama su viešųjų pirkimų igyvendinimu, yra aukštas korupcijos lygis. Ekonomistų A. Antoci ir P. L. Sacco teigimu, viešieji pirkimai gali būti prilyginami žaidimui, kuriame įmonių atstovai yra linkę imituoti tam tikrą atlyginantį veiksmą užuot ieškoję optimalaus sprendimo [4, p. 90]. Neretai aukštų valstybės tarnautojų pagrindinis pirkimų tikslas yra asmeninès naudos siekimas [33, p. 2-3]. Jie gali igyvendinti projektus, daryti menkai pagrịstus ar visiškai ekonomiškai nenaudingus pirkimus, kurie neduoda socialinès ir ekonominès naudos viešajam interesui. Korupcija ilgą laiką buvo siejama su sąžiningumo nebuvimu sistemoje, procesuose ar diegiant standartus. Procesiniai nukrypimai viešųjų pirkimų procese gali atsirasti dèl klaidų, nekompetencijos ar tiesiog iš sąmoningų sumanymų [21, p. 389; 22]. Mokslininkai, kurie analizuodami korupcijos reiškinius rèmési funkcionalistine mokykla, teigè, kad sistemos ar procesų ydas gali pakoreguoti korupcija (kyšių davimas), skatindama veiklos efektyvumą, sumažindama biurokratines kliūtis investavimui ir padedama priimti sprendimus, palankius ekonominiam vystymuisi. Remiantis švedų tyrinètojo $T$. T. Lennerfors išskirtais vertinimo kriterijais, viešųų pirkimų praktiką galima vertinti per dviejų teorijų prizmę. Deontologinė etika reikalauja tobulo viešo pirkimo proceso, kuriame akcentuojami skaidrumo, teisingumo ir iš jų išplaukiantys vienodo visų traktavimo, nediskriminacijos, abipusės pagarbos principai. Teleologiné etika siūlo orientuotis ị pasekmes, t. y. ekonominị naudingumą, todèl dèmesys skiriamas galutiniam rezultatui, mažinant ekonominių subjektų nelygybę ir verslo sprendimus orientuojant ị visuomenės bendrus interesus ${ }^{1}[24 ; 31$, p. 80$]$.

Remiantis klasikinio institucionalizmo teorija, galima teigti, kad viešųjų pirkimų procesas be reglamentuotų ir teisinèje bazèje ịtvirtintų normų negalètų būti skaidrus ir ekonomiškai naudingas valstybei bei pilietinei visuomenei. Tiksliai reglamentuotas perkančiųjų organizacijų ir tiekejjų statusas, teisès ir pareigos, atsakomybė visuomenei yra vieni svarbiausių ir kartu pamatinių klasikinio institucionalizmo bruožų. Norint užtikrinti skaidrų ir ekonomiškai naudingą viešojo pirkimo procesą, būtinos atitinkamos valstybinès institucijos, darančios įtaką ekonominių subjektų veiklai.

\section{Neoinstitucionalizmo ekonomikos teorijų analizė ir vertinimas}

Nepasitenkinimas tradicine ekonomikos teorija, tradiciniais vadybiniais metodais ir sprendimais bei valstybės institucijų nelankstumu, paskatino naujos ekonomikos mokyklos neoinstitucionalizmo ekonomikos teorijos atsiradimą XX amžiaus paskutiniaisiais dešimtmečiais. Pagrindiniai neoinstitucionalizmo bruožai viešųų pirkimų procese atsispindi per sąmoningą viešųjų pirkimų planavimo procesą, kurio rezultatas - socialiniai institutai ir institucijos.

1 Klasikinè sociologinio institucionalizmo teorija Prancūzijoje XX amžiaus 6-7 dešimtmetyje. 
Klasikinis institucionalizmas leidžia identifikuoti savaime susiformavusias perkančiąsias organizacijas ir tiekejjus, atskirti valstybejje veikiančius ekonominius subjektus - viešąji ir privatų sektorių, t. y. grupes ir organizacijas, - tačiau individualius santykius bei elgseną analizuoja iš šios teorijos atsiradusios neoinstitucinès ekonomikos teorijos. Neoinstitucionalizmas skatina ị viešųjų pirkimų procesą pažvelgti praktiškai ir veikiančius institutus analizuoti ne pagal idealias teorinio modelio sąlygas, o pagal viešųjų pirkimų praktikoje esančias alternatyvas, kas leidžia išplèsti mikroekonominę analizę. Be fizinio ir techninio ribotumo, būdingo klasikinei institucionalizmo teorijai, neoinstitucionalizmas identifikavo ir giliau analizavo visuomenès institucinę struktūrą. Ekonominèmis aplinkybėmis susiformavusi institucinė struktūra atspindi situaciją viešųjų pirkimų procese, kai valstybinių institucijų perkančiosios organizacijos turi būti suinteresuotos ekonomiškiausiu ir/arba efektyviausiu pirkimu, tuo tarpu tiekejjai (verslo organizacijos) - galimai maksimaliu pelnu atlikus viešąji pirkimą [20;28, p. 618]. Neoinstitucionalizmas neretai analizuojamas kitų krypčių ir srovių plotmèje, iš kurių paminètinos nuosavybès teisiu, transakciju (sandoriu), sutarčiu, visuomeninio pasirinkimo bei agentu ekonomikos teorijos (žr. 2 lentelę).

2 lentelè. Neoinstitucionalizmo ekonomikos teorijų viešuosiuose pirkimuose analizè

\begin{tabular}{|c|c|c|c|}
\hline $\begin{array}{l}\text { Eil. } \\
\text { Nr. }\end{array}$ & $\begin{array}{l}\text { Neoinstitucionalizmo } \\
\text { ekonomikos teorija }\end{array}$ & Autoriai & $\begin{array}{c}\text { Pagrindiniai teorijos aspektai viešuosiuose } \\
\text { pirkimuose }\end{array}$ \\
\hline 1. & $\begin{array}{l}\text { Nuosavybès teisių } \\
\text { teorija (angl. The } \\
\text { property rights } \\
\text { theory) }\end{array}$ & $\begin{array}{l}\text { Alchian, } \\
\text { Demsetz } \\
(1973)\end{array}$ & $\begin{array}{l}\text { 1. Viešųjų pirkimų teisinè bazė: Lietuvos } \\
\text { Respublikos ir Europos Sąjungos teisės aktai } \\
\text { 2. Nuosavybės perdavimas ịtvirtinamas } \\
\text { sutartimi }\end{array}$ \\
\hline 2. & $\begin{array}{l}\text { Transakcijų (sandoriu) } \\
\text { teorija (angl. The } \\
\text { theory of transaction } \\
\text { costs) }\end{array}$ & $\begin{array}{l}\text { Coase } \\
(1937)\end{array}$ & $\begin{array}{l}\text { 1. Rinka (valstybè plačiąja prasme) ir firmos } \\
\text { (perkančiosios organizacijos ir tiekejai) } \\
\text { 2. Socialiniai kaštai lygūs privačių ir išorinių } \\
\text { kaštų sumai (ekonomiškumo ir skaidrumo } \\
\text { problemos viešujų pirkimų procese } \\
\text { identifikavimas) }\end{array}$ \\
\hline 3. & $\begin{array}{l}\text { Sutarčiu teorija } \\
\text { (angl. The theory of } \\
\text { contracts) }\end{array}$ & $\begin{array}{l}\text { Meckling, } \\
\text { Jensen } \\
(1976)\end{array}$ & $\begin{array}{l}\text { 1. Sudėtingas tinklas, paremtas geresnio firmos } \\
\text { tipo paieškomis } \\
\text { 2. Ilgalaikių santykių plètra } \\
\text { 3. Perkančiųjų organizacijų, tiekejjų ir Viešųjų } \\
\text { pirkimų tarnybos kontroliuojama veikla } \\
\text { igyvendinant sutarti } \\
\text { 4. Normomis paremtas administracinis } \\
\text { koordinavimo mechanizmas ir monitoringas } \\
\text { (stebėsena) } \\
\text { 5. Investicinis mechanizmas, susijęs su } \\
\text { elektroninių viešųų pirkimų plètra }\end{array}$ \\
\hline
\end{tabular}


2 lentelès tęsinys

\begin{tabular}{|c|c|c|c|}
\hline 4. & $\begin{array}{l}\text { Viešojo pasirinkimo } \\
\text { teorija (angl. The } \\
\text { public choice theory) }\end{array}$ & $\begin{array}{l}\text { Arrow } \\
(1963) \\
\text { Buchanan, } \\
\text { Tullock } \\
\text { (1958) } \\
\text { Eisenhardt } \\
(1989)\end{array}$ & $\begin{array}{l}\text { 1. Asmeninių interesų siekimas, individo } \\
\text { racionalumo principas (naudos ir kaštų } \\
\text { santykis) } \\
\text { 2. Korupcinių sanderrių sudarymas tarp } \\
\text { perkančiųų organizacijų ir tiekèjų (kyšiai) } \\
\text { 3. Politinė rinka } \\
\text { 4. Užsakovo (perkančioji organizacija) - } \\
\text { vykdytojo (tiekėjas) interesų egzistavimo } \\
\text { problema }\end{array}$ \\
\hline
\end{tabular}

Nuosavybès teisiu ekonomikos teorija yra siejama su A. A. Alchian ir H. Demsetz, kurie institucionalizmą apibrèžè kaip normų, kurios reguliuoja ribotų išteklių pasisavinimą, visumą [2, p. 16]. Remiantis šia nuostata, viešųjų pirkimų procese plačiausius igaliojimus teisiniu požiūriu turi perkančioji organizacija, kuri ne tik planuoja ir organizuoja viešąji pirkimą, bet ir turi sprendimo teisę dèl konkurso nugalètojo paskelbimo. Tuo tarpu tiekèjo statusas išlieka formalus ir pasireiškia per teisingą konkurenciją rinkoje, nepažeidžiant ịstatymuose ịtvirtintų taisyklių. Pagal nuosavybės teisių ekonomikos teoriją, pagrindinis tikslas viešujų pirkimų procese pasirašyti viešojo pirkimo-pardavimo sutartị, t. y. keistis ištekliais ir gauti kuo daugiau teisinių igaliojimų ištekliui (prekès, paslaugos ir darbai). Akcentuotina, kad pirkimo sutartyje, kai ji sudaroma raštu, turi büti nustatyta: sutarties šalių teisès ir pareigos, perkamos prekès, paslaugos ar darbai, jeigu ịmanoma, tikslūs jų kiekiai, kaina arba kainodaros taisyklès, atsiskaitymų ir mokejimo tvarka, prievolių îvykdymo terminai, prievolių ịvykdymo užtikrinimas, ginčų sprendimo tvarka, sutarties nutraukimo tvarka, sutarties galiojimas, jeigu sudaroma preliminarioji sutartis - jai būdingos nuostatos [23, p. 73].

Pagal nuosavybės teisių ekonomikos teoriją, nuosavybės teisių balansas susijęs su nuosavybès teisių ịsigijimu ir dideliais kaštais, kas neretai kelia daug diskusijų mokslininkų darbuose, kadangi sunku iš anksto numatyti realius kaštus ir realią naudą. Tik iggyvendinus konkretų viešaji pirkimą ir ịvykdžius viešojo pirkimo-pardavimo sutarties sąlygas, galima ịvertinti ir daryti išvadas, kiek ịdèti kaštai atspindi realią ekonominę naudą. Teisinèje sistemoje viešųjų pirkimų konkursai yra priverstiniai, nes savanoriški pirkimai atneštu didelius kaštus tiekẻjams. Sudètingiausi reiškiniai, analizuojami ekonomistų darbuose, yra ekonominių veiksnių ịtaka teisinei sistemai, kai iš praktikos gimsta normos. Tokie reiškiniai pasireiškia tada, kai rinka nebegali efektyviai funkcionuoti nereguliuojant teisinėmis normomis [35, p. 1].

Dar XX amžiaus ketvirtajame dešimtmetyje R. Coase iškẻlè klausimą, kodèl egzistuoja firmos, jeigu yra rinkos. Rinkos egzistavimas padeda vertinti kaštus, kontroliuoti ir stebèti firmų veiksmus. Transakciju (sandoriu) ekonomikos teorijoje rinkos mechanizmo panaudojimo kaštai buvo ịvardinti kaip transakciniai kaštai, kuriuos firmos (perkančiosios organizacijos ir tiekejjai) naudoja efektyviau nei rinka. Firmos administracinis aparatas veikia pagal konkrečias funkcijas, iggaliojimus 
bei pavedimus [13, p. 386]. Firmų augimo procesas viešuosiuose pirkimuose siejamas su perkančiųjų organizacijų ir tiekejjų autonomija, laisve priimti ekonomiškai naudingus sprendimus dèl dalyvavimo pirkimų procese, pasikeitimo ištekliais ir panaudojimo viešajam interesui. Akcentuotina, kad ekonominiu požiūriu institucinio aparato augimas gali padidinti kaštus ir ne visada duoti laukiamų rezultatų. Institucijų augimo procesas ypač pastebimas po $2004 \mathrm{~m}$. Lietuvos įstojimo i Europos Sąjungą. Šiandien informacinès visuomenès kūrimas Europos Sąjungoje tapo vienu pagrindinių prioritetų. Elektroniniai viešieji pirkimai padeda sumažinti biurokratiją bei supaprastinti oficialias procedūras, taupomas valstybès tarnautojų laikas bei valstybės pinigai, pagerinama ịsigytų produktų ir paslaugų kokybė, skatinama tiekejjų konkurencija, didinami viešujų tarnybų rezultatai: skatinamas viešojo ir privataus sektorių bendradarbiavimas, stiprèja išorinès aplinkos ir socialinis Vyriausybės vaidmuo [7, p. 3]. Igyvendinus projektą „Centrinès viešujų pirkimų informacinès sistemos plètra“, 2008 m. rugpjūčio mènesị ịvykdytas pirmasis elektroninis viešasis pirkimas Lietuvoje. Ekonominis efektyvumas ne tik padeda mažinti kaštus, nustato griežtas nuosavybès ribas, bet ir sudaro sąlygas paskirstyti nuosavybès teises. Rinkos veikla turi būti palaikoma, todèl pageidautinas tiesioginis rinkos dalyvių skatinimas.

Sutarčiu teorija iškelia klausimą, koks firmos tipas yra geriausias. Kiekviena sandorio šalis yra linkusi elgtis savanaudiškai ir jeigu tik įmanoma ji pasinaudoja kitos šalies trūkumais, todèl reikalinga nuolatinè kontrolè [43, p. 223-224]. Ši teorija neapsiriboja sudètingo sutarčiu tinklo aprašymu, tačiau gilinasi ị ilgalaikių sutartinių santykių paieškas, efektyvesnès organizacinès struktūros kūrimą. Pabrèžtina perkančiųjų organizacijų, tiekèjų ir Viešųjų pirkimų tarnybos kontroliuojama veikla ịgyvendinant viešojo pirkimo-pardavimo sutartį. Mokslinèje literatūroje viešųjų pirkimų procesas neatsiejamas nuo normomis paremto administracinio koordinavimo mechanizmo ir monitoringo (stebėsena). Investicinis mechanizmas pagal sutarčių teoriją yra susijęs su elektroninių viešųjų pirkimų pletra [26, p. 2-3]. Kaip teigia E. Vitkauskaite, R. Gatautis ir D. Neef, viešųų pirkimų procese turi būti atsižvelgiama ị visus techninius dokumentus, todèl svarbūs yra ir tiekẻjo pajëgumai dalyvauti viešųjų pirkimų konkurse. Būtina atsižvelgti ị keletą aspektų: ar tiekejjas gali pasiūlyti visą kompleksą prekių arba paslaugų, reikalingų perkančiajai organizacijai konkrečiu momentu (pvz., pastatas, dalinis pastatas, visų lygių produktai ir medžiagos bei kt.); ar tiekejjas gali pasiūlyti specifines paslaugas (pvz., projektavimas, dizainas, inžineriniai skaičiavimai ir pan.); ar investuoti palankiau perkančiajai organizacijai, ar investuotojui; ar reikalinga ịsigyti prekę arba paslaugą, galbūt yra galimybė nuomotis [18; 27; 41]. Didèjanti konkurencija gerina klientų aptarnavimo kokybę, o sutrumpinta tiekimo grandinè atpigina prekes ar paslaugas. Pasak J. E. J. Prins, itin svarbios valstybès modernizavimui bei žinių ekonomikos plètrai yra elektroninio verslo ir elektroninès valdžios sritys [32]. Anot A. A. Alchian ir H. Demsetz, valstybinių institucijų valdymas lyginant su privačiomis skiriasi tuo, kad jos negali tiesiogiai dalyvauti organizacijos valdyme, kadangi valstybinių ins- 
titucijų savininkai yra mokesčių mokètojai, o valstybės tarnautojai yra jų atstovai [2, p. 17].

Viešojo pasirinkimo teorijos pradininkai K. J. Arrow, J. Buchanan ir G. Tullock padejo susiformuoti šiai neoinstitucionalizmo krypčiai XX amžiaus šeštajame-septintajame dešimtmečiuose. Mokslininkų darbuose identifikuojamas esminis teorijos bruožas - asmeninių interesų siekimas politinèje sferoje. Autorių teigimu, nėra neịveikiamos ribos tarp politikos ir verslo, kadangi žmonès naudojasi visuomeniniais institutais ir institucijomis siekdami asmeninių interesų bet kokia kaina $[5 ; 10]$. Naujoji viešoji vadyba ir institucionalizmas būtinumą vykdyti valdymo reformas sieja ne tik su naujų metodų diegimu, bet ir galimybe perimti privataus sektoriaus vertybes bei darbo principus. Elektroninès valdžios teikiama nauda yra neatsiejama nuo naujų galimybių ir iššūkių verslui, didesnès teikiamų paslaugų paklausos, bendrojo vidaus produkto augimo [34]. Elektroninès priemonès yra būtinos siekiant sumažinti valstybès išlaidas ir užtikrinti, kad viešųjų pirkimų procesai vyktų sklandžiau ir skaidriau. A. Guogis ir D. Gudelis teigia, kad biurokratai savo prigimtimi nesiskiria nuo kitų žmonių, deklaracijos apie biurokratų pastangas rūpinantis visuomeniniu gériu tėra apgaulè ir priedanga siekiant asmeninès naudos [19, p. 27].

Tikslinga kurti projektus, kurie būtų orientuoti ị viešųjų pirkimų optimizavimą ir efektyvumo didinimą, integruojant elektroninę valdžią ir elektroninị verslą. Remiantis K. M. Eisenhardt, agentu teoriją identifikuoja užsakovo (perkančioji organizacija) - vykdytojo (tiekejjas) (angl. agent) interesų egzistavimo problema. Pagrindinis šios teorijos klausimas, kaip garantuoti, kad agentai atliktų tai, ko iš jų reikalauja užsakovas [16, p. 57-58]. Užsakovo ir vykdytojo santykiuose iškyla moralès ir išsisukinejjimo problemos. Agentas elgiasi savanaudiškai ir vengia vykdyti savo ịsipareigojimus, jeigu tik žino, kad už tai nebus nubaustas. Agentūros yra vienas iš naujojo viešojo valdymo požymių, kai privataus sektoriaus bei rinkos ypatumai gali būti panaudojami ir jas kuriant. Tarp vertybių, kurias perima naujai kuriamos valdžios judejimas ir naujasis viešasis valdymas, yra konkurencija, rinkos mechanizmai ir pagarba verslo dvasiai. Naujosios viešosios vadybos mokykloje orientuojamasi į viešojo ir privataus sektoriaus bendradarbiavimą, siekiant efektyviau teikti paslaugas piliečiams. Sąvokos naujasis viešasis administravimas ir naujoji viešoji vadyba dažniausiai vartojamos kaip sinonimai. Tuo tarpu naujojo viešojo valdymo (angl. New public management) šaknys glūdi pasaulineje viešojo administravimo raidoje, ịvardijamoje terminu vyriausybès perkūrimas (angl. Reinventing government), ir konceptualioje sąsajoje su viešąja politika. Remiantis J. Alford ir O. Hughes, naujasis viešasis valdymas suvokiamas ne kaip nauja normatyviné paradigma, o kaip geriausias valdymo sprendimų kelias arba institucionalizmo minties plètoté neoinstitucionalizmo teorijoje [3, p. 131].

Remiantis D. Osborn ir T. Gaebler, rinkos modeli pirmiausiai reikètų taikyti paslaugų teikejjams, o ne politikos arba priežiūros institucijoms. Kur įmanoma, rinkos modelis, pritaikytas vyriausybei, turès konkurencijos tarp valstybinio ir privataus sektoriaus požymių, konkurencijos tarp privačiu įmonių, besivaržančių dèl 
sutarčių su valstybe, konkurencijos tarp valstybinių įstaigų ir konkurencijos tarp vyriausybės padalinių, teikiančių paslaugas vidaus vartotojams, požymių. Toks rinkos modelis remiasi valdoma arba kontroliuojama konkurencija, kurioje vyriausybė išlaiko ịgaliojimus ir atsakomybę už taisyklių nustatymą [30]. Mokslininkų teigimu, ị rinką orientuotos vyriausybinès programos turi daugiau pranašumų, kadangi jos yra decentralizuotos, konkurencinès, reaguojančios ị kintančias sąlygas bei suteikia pasirinkimo laisvę vartotojams.

Išskirtinis neoinstitucionalizmo bruožas, lyginant šią ekonomikos kryptị su klasikiniu institucionalizmu, yra tas, kad pagrindinis mokslininkų ir praktikų dèmesys sutelkiamas ties ryšių tarp atskirų institutų ir institucijų analize, ne tik jų identifikavimu. Mokslinėje literatūroje išryškinamas valstybès vaidmuo ekonominiame bei politiniame procesuose, pripažistama korupcijos, biurokratijos ir lobizmo itaka, prognozuojami ir numatomi galimi sprendimai šioms politinèms problemoms spręsti.

\section{Viešųjų pirkimų procesas institucionalizmo teorijoje}

D. C. North teigimu, institucijos yra visuomenès žaidimo taisyklès, kartu tai žmonių sukurti bet kokios formos apribojimai, formuojantys žmogiškąją sąveiką [29]. Pagal S. J. Burki ir G. Perry, institucijos yra apibrèžiamos kaip formalios ir neformalios taisyklès bei jų vykdymą užtikrinantys mechanizmai, formuojantys individų ir organizacijų elgesị visuomenèje [11]. Pasak S. Voigt ir H. Engerer, institucijas sudaro „taisyklių komponentas“ ir „,vykdymo arba sankcijų komponentas“ [42].

Institucionalizmo orientacija ị socialinị ir ekonominį vystymąsi valstybejje igalina viešųjų pirkimų procese neskirstyti pirminių ir antrinių institutų ir juos analizuoti kaip visumą. Viešujų pirkimų procese institutų visuma susideda iš nacionalinių ir transnacionalinių (Europos Sąjungos) viešuosius pirkimus reglamentuojančių teisès aktų (formalių taisyklių), formalių ir neformalių santykių tarp perkančiųjų organizacijų ir tiekẻjų (formalus pasiruošimas viešojo pirkimo konkursui, derybos, paklausimų siuntimas, neformalūs korupcinio pobūdžio išankstiniai susitarimai ir kt.) bei viešųjų pirkimų tvarką užtikrinančių prievartos priemonių. Pasaulio banko ataskaitoje išskiriamas naujas požiūris ị ekonomikos vystymąsi, akcentuojant institucijų vaidmenị sprendžiant ekonominès nelygybès klausimus [44]. Pažymètina, kad Europos Sąjungos valdžios sektoriaus pajamos sudaro maždaug 45 proc. bendrojo vidaus produkto (BVP), o valstybinių valdžios institucijų vykdomi viešieji pirkimai - 15-20 proc. BVP arba 1500-2000 mlrd. EUR per metus [36]. Teisès viršenybė siejama su nuosavybès teisių apsauga ir maža korupcija, todèl šiuos aspektus ịvertinantys indeksai gali būti traktuojami kaip alternatyvūs teisès viršenybę atspindintys rodikliai [12, p. 648-649]. Egzistuoja stiprūs ryšiai tarp korupcijos masto, biurokratijos kokybės ir teisès viršenybę ịvertinančių rodiklių [39]. Kadangi institucijos nekuria prekių ir paslaugų, mokslinejje literatūroje ir praktikų ataskaitose jų poveikis gamybos apimčiai yra netiesioginis ir siejamas su poveikiu 
investicijoms, žmogiškajam kapitalui ir naujų technologijų kūrimui. D. Acemoglu, S. Johnson ir J. A. Robinson akcentavo politinių ir ekonominių institucijų tarpusavio sąryši [1, p. 391].

Institucionalistų požiūriu, valstybè ir teisè - tai dvi neatsiejamos sąvokos. Ekonomika yra teisinès kontrolès objektas, o valstybè - ekonominès naudos gavimo priemonè. Elektroninès valdžios priemonių kūrimas ir diegimas yra neatsiejamas nuo aukštụjų technologijų plètros, šalies inovacijų skatinimo politikos ir žinių ekonomikos raidos. Informacinès ir ryšių technologijos (toliau - IRT) (angl. Information and communication technologies), moksliniai tyrimai ir jų rezultatų pritaikymas praktikoje gali padèti patobulinti egzistuojančius elektroninius procesus, operacijas ir paslaugas. Elektroninès valdžios projektai atskleidè didžiules valstybių socialinès ir ekonominès raidos galimybes, tačiau jų išnaudojimas priklauso ne tik nuo politinès valios, bet ir nuo technologinių sprendimų bei egzistuojančių intelektinès nuosavybės režimų ir paskatų plètoti žinioms imlias sritis. Šiuolaikinè, greitai kintanti ir kompleksiška žinių visuomenė formuoja vis naujus iššūkius elektroninès valdžios sprendimams, todèl keliami reikalavimai tobulinti IRT naudojimą ir pritaikyti vis modernesnes technologines priemones, iggalinančias greitesnę, paprastesnę ir labiau prieinamą komunikaciją [6]. Valstybės modernizavimui bei žinių ekonomikos plètrai itin svarbios yra elektroninès valdžios sritys [32]. Institucionalistinès mikroekonomikos pagrindinis teiginys - išteklių paskirstymas yra ne rinkos, o valdžios struktūros funkcija. Valdžia ir jos institucijos sukuria rinką ir per ją veikia, paskirsto pajamas ir pinigų srautus.

Institucionalistai didelị dèmesị skiria individų elgsenos ekonominių ir politinių motyvų aiškinimui. I individą siūloma žiūrèti ne kaip ị atskirą subjektą, o kaip ị socialinès sistemos dalị. Hierarchinè valstybès tarnautojų ir politikų atsakomybè gali iš esmès pakeisti jų požiūrị ị viešuosius pirkimus ir paskatinti juos veikti vengiant viešų ir privačių interesų konflikto [20]. Institucionalizmas gali būti apibrěžiamas kaip socialinès kontrolès ir pasikeitimų teorija, kurioje daug dèmesio skiriama nuosavybei, korporacijoms ir, žinoma, valstybei. Galima ịžvelgti, kad informacinės technologijos suteikia naujų galimybių stebėti viešojo pirkimo procesą nuo poreikio pirki identifikavimo iki sutarties vykdymo kontrolès.

\section{Išvados}

1. Viešieji pirkimai yra nauja praktika, taikoma Lietuvos viešajame sektoriuje. Nors viešieji pirkimai siejami su valstybės léšų taupymu ir efektyviu jų paskirstymu, viešujų pirkimų praktika rodo, kad naujosios viešosios vadybos idejos perimtos tik iki tam tikro laipsnio. Institucionalizmo pagrindinis tyrimų objektas yra ne kainodara ar išteklių paskirstymas, o organizacija ir kontrolè. Institucijų funkcijų apibrezžimas, valdžios struktūros nustatymas yra esminiai svertai analizuojant institucinės ekonomikos teorijų raišką viešųjų pirkimų procese. Nuo viešųjų pirkimų teisinio reglamentavimo pradžios ši prekių, paslaugų ar darbų ịsigijimo tvarka susi- 
laukia visuomenės kritikos dèl neadekvačiai didelių prekių, paslaugų ar darbų kainų, kurias sumoka perkančiosios organizacijos iš mokesčių mokètojų pinigų. Kita problema - nepakankamai užtikrintos tiekèjų konkuravimo dèl sutarčių sąlygos bei skaidrumo problema.

2. Atliekant viešųjų pirkimų kontrolę, nepakankamai dėmesio skiriama viešojo pirkimo sutarties ex-ante kontrolei, t. y. neišnaudojamos kompleksinès vadybos priemonès, siekiant išvengti rimtų Viešųjų pirkimų įstatymo pažeidimų. Galima teigti, kad tikslinga peržiūrèti ir nustatyti Viešųjų pirkimų tarnybos veiklos prioritetus, didesnį dėmesị skirti išankstinei viešųjų pirkimų kontrolei, metodinès pagalbos ir konsultacijų perkančiosioms organizacijoms ir tiekejjams teikimui. Institucionalizmas leidžia struktūriškai analizuoti viešųjų pirkimų procesą ir jo dedamąsias ekonominiu požiūriu. Pasakytina, kad viešųjų pirkimų proceso organizavimo klausimas reikalauja nuodugnesnès analizès viešujų pirkimų procesą skaidant $i$ atskirus etapus, identifikuojat veikiančius institutus ir institucijas.

3. Pagrindinès institucionalistų metodologinès nuostatos viešųjų pirkimų procese gali būti apibendrintos taip: ekonominių procesų prognozavimas leidžia prognozuoti perkančiųjų organizacijų ir tiekẻjų veiksmus; ekonominių procesų prognozavimas turi turèti aiškias prognozavimo ribas; ekonominiai procesai negali būti suprantami statiškai, kadangi technologinė pažanga skatina ieškoti naujų sprendimų; sprendžiamos konkrečios ūkinès problemos bei politinès dilemos ekonominèje teorijoje, orientuojantis ị viešojo pirkimo proceso supaprastinimą biurokratijos požiūriu; pripažịstamas vertybinių sprendimų būtinumas.

\section{Literatūra}

1. Acemoglu, D.; Johnson, S.; Robinson, J. A. Institutions as the fundamental cause of long-run growth. Handbook of Economic Growth. Amsterdam: North Holland, 2005, 389-476.

2. Alchian, A. A.; Demsetz, H. The Property Rights Rights Paradigm. The Journal of Economic History, 1973, Vol. 3, 16-27.

3. Alford, J.; Hughes, O. Public Value Pragmatism as the New Phase of Public Management. American Review of Public Administration, 2008, Vol. 38, No. 2, $130-148$.

4. Antoci, A.; Sacco, P. L. A public contracting evolutionary game with corruption. Journal of economics, 1995, Vol. 61, No 2, 89-122.

5. Arrow, K. J. Social Choice and Individual Values, 1963. http://cowles.econ.yale. edu/P/cm/m12-2/ [2013-12-01].

6. Barnes, S.; Hunt, B. E-commerce and v-business - Business Models for Global Success. Great Britain, 2001.

7. Bof, F.; Previtali, P. Organisational Pre-Conditions for e-Procurement in Governments: the Italian Experience in the Public Health Care Sector. Electronic Journal of e-Government, 2007, Vol. 5, No.1, 1-10.

8. Boumans, M.; Davis, J. B. Economic methodology: understanding economics as a science Basingstoke. Palgrave, Macmillan, 2010. 
9. Brockhaus - die Enzyklopädie: in 24 Bänden. Leipzig: Brockhaus, 1997.

10. Buchanan, J.; Tullock, G. The Calculus of Consent: Logical Foundations of Constitutional Democracy, 1958. http://www.econlib.org/library/Buchanan/ buchCv3.html [2013-12-01].

11. Burki, S. J.; Perry, G. Beyond the Washington Consensus: Institutions Matter. Washington: World Bank, 1998.

12. Butkiewicz, J. L.; Yanikkaya, H. Institutional quality and economic growth: maintenance of the rule of law or democratic institutions, or both? Economic Modeling, 2006, No 23 (4), 648-661.

13. Coase, R. The Nature of the Firm. Economica. Blackwell Publishing, 1937, No 4 (16), 386-405.

14. Crystal, D. The Penguin concise encyclopedia. London: Penguin, 2003.

15. Der Brockhaus: in einem Band. Leipzig: F. A. Brockhaus, 1996.

16. Eisenhardtm, K. M. Agency theory: An assessment and review. Academy of Management Review, 1989, Vol. 14, No. 1, 57-74.

17. Erridge, A. Public procurement, public value and the Northern Ireland unemployment pilot Project. Public Administration, 2007, Vol. 85, No 4, 1023-1043.

18. Gatautis, R. The Impact of ICT on Public and Private Sectors in Lithuania. Engineering Economics, 2008, No. 4(59), 18-28.

19. Guogis, A.; Gudelis, D. Naujosios viešosios vadybos taikymo teoriniai ir praktiniai aspektai. Viešoji politika ir administravimas, 2003, Nr. 4, 26-34.

20. Handbook of new institutional economics. Berlin: Springer, 2008.

21. Hoff, K.; Stigliz, J. E. Modern Economic Theory and Development. The World Bank, 1999, 389-459.

22. Hungtinton, S. P. Political order in changing societies. Yale: University Press, 1968.

23. Junevičius, A.; Ereminaitè, S. Viešųjų pirkimų optimizavimo ir efektyvumo didinimo galimybès. Organizacijų vadyba: sisteminiai tyrimai, 2010, Nr. 54, 67-84.

24. Lennerfors, T. T. The transformation of transparency - on the act on public procurement and the rigth to appeal in the context of the war on corruption. Journal of business ethics, 2007, Vol. 73, 381-390.

25. Lietuvos Respublikos viešųjų pirkimų įstatymas. Valstybès žinios, 2013-10-26, Nr. 1491.

26. Meckling, W.; Jensen, M. Theory of the Firm: Managerial Behavior, Agency Costs and Ownership Structure. Journal of Financial Economics, 1976, Vol. 3, No. 4, $305-$ 360. http://www.sfu.ca/ wainwrig/Econ400/jensen-meckling.pdf [2013-12-01].

27. Neef, D. E-procurement - from strategy to implementation. United States of America: Prentice Hall PTR, 2001.

28. New Institutional Economics: A Guidebook. Cambridge University Press, 2008.

29. North, D. C. Institucijos, ju kaita ir ekonomikos veikmé. Vilnius: Eugrimas, 2003.

30. Osborne, D.; Gaebler, T. Reinventing Government: How the Entrepreneurial Spirit is Transforming Public Sector. Addison-Wesley Publishing Company, 1992.

31. Palidauskaitè, J.; Ereminaitè, S. Korupcija viešuosiuose pirkimuose: nuo teorinès apibrěžties link atvejo studijos (I dalis). Viešoji politika ir administravimas, 2010, 32, 74-84. 
32. Prins, J. E. J. Designing E-Government. On the Crossroads of Technological Innovation and Institutional Change. Hague: Kluwer Law International, 2002.

33. Rossiaud, S.; Locatelli, C. Institutional Economics. Polinares working paper n.12, 2010.

34. Schubert, P.; Häusler, U. E-Government meets E-Business: A Portal Site for Startup Companies in Switzerland. Proceedings of the 34th Hawaii International Conference on System Sciences, 2001.

35. Scott, K. The Price of Politics - Lessons from Kelo V. City of New London. Rowman \& Littlefield, 2010. http://books.google.lt/books?id=fHFHk19OzA4C\&printsec=fro ntcover\&hl $=1$ t\&source $=$ gbs_ge_summary_r\&cad $=0 \# \mathrm{v}=$ onepage \&q\&f=false [201311-30].

36. Statistics reports under Article XIX:5 of the GPA. World Trade Organization, 2010. http://www.wto.org/english/tratop_e/gproc_e/gpstat_e.htm [2013-06-05].

37. Surandas, A. Viešieji pirkimai. Viešuju pirkimu tarnybos prie Lietuvos Respublikos Vyriausybès informacinis biuletenis, 2002, 1(2).

38. The new international Webster's comprehensive dictionary of the English language. Naples: Trident press international, 1996.

39. Treisman, D. The causes of corruption: a crossnational study. Journal of Public Economics, 2000, No. 76 (3), 399-457.

40. Urbonas J., A.; Maksvytienė, I.; Sabonienè, A. Ekonomikos teorijos: praeitis ir dabarties tendencijos: mokomoji knyga. Kaunas: Technologija, 2011.

41. Vitkauskaite, E.; Gatautis, R. E-procurement perspectives in construction sector SMEs. Journal of Civil Engineering and Management, 2008, Vol. 14, No. 4.

42. Voigt, S.; Engerer, H. Institutions and transition: possible policy implications of the new institutional economics, 2001. http://ssrn.com/abstract=294384 [2013-12-01].

43. Williamson, O. E. Transactions Cost Economics: The Governance of Contractual Relations. Journal of Law and Economics, 1979, No. 22, 223-261.

44. World Bank. World Development Report 2006: Equity and Development. New York: Oxford University Press, 2006.

\title{
Simona Ereminaite \\ Expression of Institutional Economic Theories in Public Procurement Process
}

\begin{abstract}
Public procurement is a relatively new practice of the institutions in public sector associated with the new ideas in public management: to take over the business management principles and adapt them to the public institutions, to save the state money, to efficiently distribute and promote public and private sectors. Institutionalism is described of the 19th-20th centuries, especially when the focus is on the social and economic development of the country, economic problems, appropriate solutions for the public and the private sectors in the search, without distinction between primary and secondary institutions, and analyzing them as a whole in the public procurement process.
\end{abstract}


According to an independent economic institutionalism theory direction, the public procurement process can be understood as a set of institutions with an exceptional inter-relationship between purchasers and suppliers, as well as affecting the economic development of the country. The institute in the procurement process consists of: 1) the formal rules governing public procurement procedures, and informal relations between contracting authorities and suppliers, affecting both their mutual relations and their common agreements and economic development activities, 2) the coercive measures imposed to ensure public procurement procedure norms, sanctions and violence in defiance of state of the Republic of Lithuania procurement legislation. In the public sector, public procurement plays a dominant role in procurement services, law enforcement processes, health, social services, education, defense, transport and the environmental issues sectors, and therefore, to achieve public policy objectives and meet civil society needs in the public sector organizations in the procurement volume is much larger than in the private sector.

Institutionalism allows the identification of self-formed purchasers and suppliers to separate the network of economic actors' public and private sectors, groups and organizations. In the relationship between individual behavior and analyses of these theories, new institutional economic theory is born. New institutionalism encourages looking at the practical and effective institutions in the procurement process, analyzing not under the ideal conditions of a theoretical model, and according to the public procurement law with the alternative, which allows to extend the micro-economic analysis. In addition to physical and technical limitations inherent in classical institutionalism theory, new institutionalism identified and further analyzed the institutional structure of the society. The institutional structure formed in economic circumstances reflects the situation in the procurement process, the state authorities of the contracting authority must be interested in a cost-effective and/or efficient purchasing, while suppliers (business organizations) the maximum profit possible after the procurement.

Simona Ereminaite - Mykolo Romerio universiteto Politikos ir vadybos fakulteto doktorantè, vadybos ir verslo administravimo magistrè.

E. paštas: simona.ereminaite@mruni.eu

Simona Ereminaite, Master of Management and Business Administration, Mykolas Romeris University, Institute of Public Administration, PhD student.

E-mail: simona.ereminaite@mruni.eu

Straipsnis įteiktas redakcijai 2014 m. vasario 13 d.; recenzuotas; parengtas spaudai $2014 \mathrm{~m}$. gegužès $22 \mathrm{~d}$. 